\title{
Effects Of Human Resource Value Chain On Firm Performance Based On
}

\section{Synergies}

\author{
LinlinSun ${ }^{1, a^{*}}$ \\ ${ }^{1}$ Yunnan Normal University Business School, Kunming, Yunnan Province, 650106, China \\ aemail:fanxi0529@sina.com
}

Keywords: human capital theory; development status; economic

\begin{abstract}
According to the new theory of economic growth and human capital theory (Schultz), human resources as an intangible asset, it is compared with the other factors of production of natural resources, technology, capital, when it is deeply penetrated into society when the system is running, created by the competitive advantage increasingly difficult to imitate, and persistent. Human resources as a subsystem of the social system, development and management of human resources and give full play to their potential to enhance the competitiveness of the region continued to have a very important position, and therefore the area of human resources development and management performance measure were found regional human resource development and management in the problems of human resource development and management for the region and contribute to regional strategic objectives provide important basis for decision making.
\end{abstract}

\section{Introduction}

A comprehensive evaluation of the effectiveness of regional human resource development and management, need to be using the system theory analysis, to understand the internal and external coordination structure and function of the elements of the system, and the system [1,2]. Man and things reflect regional human resource development and management system human resources planning systems, human resources systems, human resources training and development systems, human resources protection and evaluation system subsystems, interpersonal coordinated operation status capacity and trends of complex dynamic systems [3-6].

In each subsystem, the "human resource planning system" is the basis for other subsystems running [7]. The main feature of the system is running: demand planning of human resources based on regional economic development strategy, and then based on demand forecast results, deployment of personnel internal and external recruitment planning [8]. This event will provide the basis for configuration, training and development, use, evaluation, protection of human resources activities of human resources. Configuring the system includes new talent into the rational allocation and distribution functions of the post for the entire region, it is based on predictions made by the human resource needs of the rational allocation of staff. Human resource training and development system is mainly through the training of human resources, improve the quality of human resources in the region to meet the needs of regional economic development and employee self-development [9]. The protection and job evaluation system includes assessment level, to develop a reasonable salary structure, based on performance evaluation results, to achieve the employee pay for performance. Employees of enterprises and improving the quality of human resources planning and will configure some impact, it would also lead to adjust and change the incentives [10]. 
Under a unified framework for analyzing the impact of enterprises' salary system, employee risk aversion and synergies and other incentives to teamwork. Studies have shown that: the higher the team into a higher degree of risk aversion and a strong synergy in favor of teamwork and higher bonuses and a lower degree of risk aversion is not conducive to the promotion of teamwork and theoretical analysis results confirmed: easier to achieve a high degree of risk aversion among co-workers, a higher degree of moderate size of team cooperation, too small or too large teams work are low level of cooperation.

\section{Regional Human Resource Development Coordination And Management System}

In short, the Regional Human Resource Development and Management System is a vibrant and dynamic system, the structure of its internal elements and interaction between them determine the functional areas of human resources development and management system that is fully developed use of regional human resources to maintain intelligence capital competitive advantage.

Regional Human Resource Development and Management System Coordination System Coordination refers to the so-called co-evolution of the system structure and function. Coordinate system is the inherent requirement of the system integrity, its purpose is to reduce the negative effects of the system and improve overall output and the overall effect of the system, allowing the system to achieve the status of synergistic or harmony. First, the area of human resources development and management itself as a system, including internal and mutual coordination between the various subsystems within the system, namely, human resource planning, configuration, training and development, etc., evaluation and protection of the internal subsystems and their interrelationships mutual integration in terms of function, structure and the interaction, as well as finance, production, marketing, and other subsystems of coordination and cooperation; secondly, as a subsystem of the social area of the system, human resources development and management system and regional needs other subsystem, such as the coordination of economic system, political system, labor market systems. According to the analysis of the above factors and the operation of the functional area of human resource development and management system, regional human resources development and management system diagram was shown in Figure 1. 


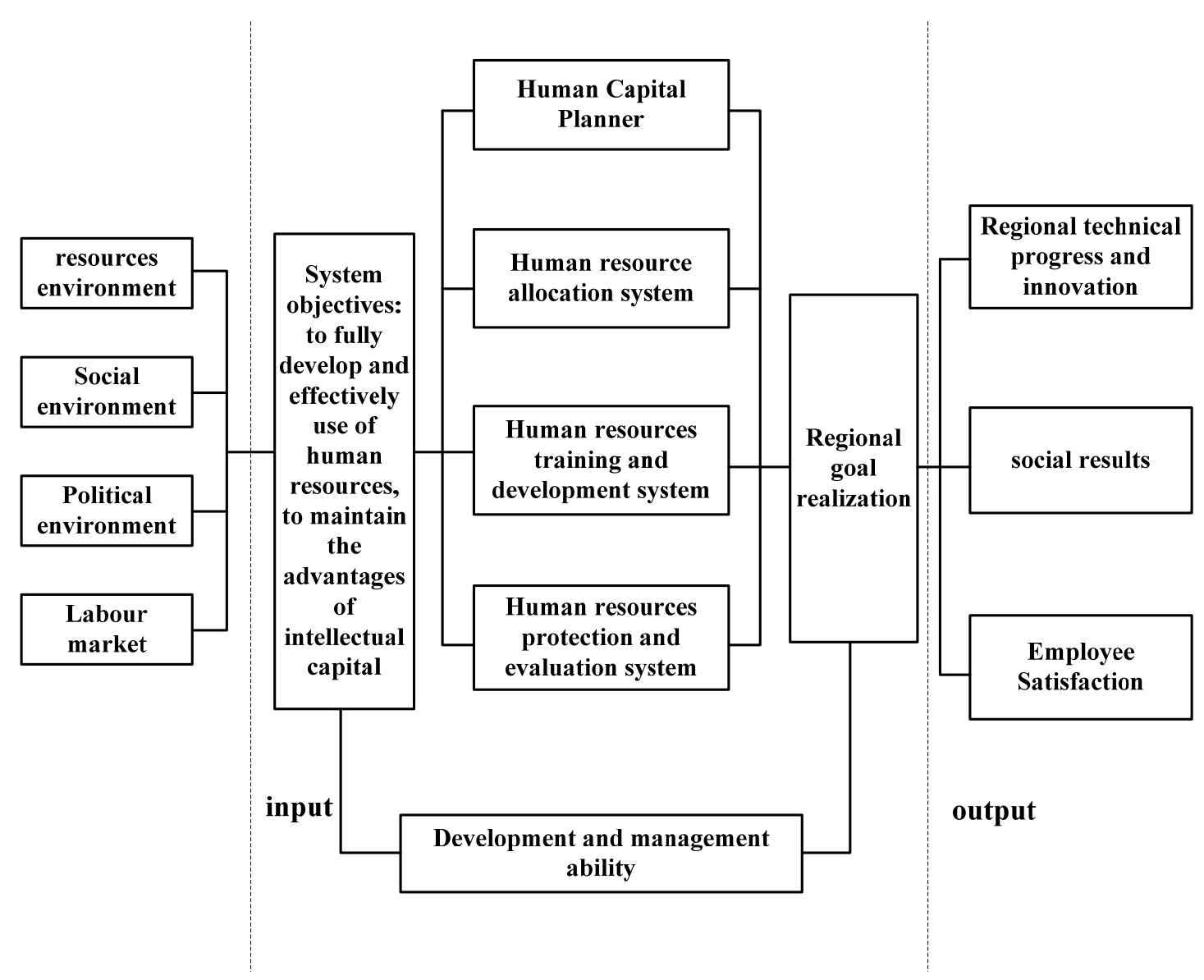

Figure 1. Regional human resources development and management system diagram

\section{Management Evaluation System}

Regional Development and Human Resource Management Evaluation Index System Construction to reveal the full and effective regional human resources development and management, this article from system theory, combined with human capital theory and the theory of human resource management, internal and external coordination, functioning of validity, achieve the objective of the three dimensions in accordance with systematic, scientific, objective consistency, operability and comparability principles reveal the performance of regional human resources development and management system. Regional Development and Human Resource Management Evaluation Index System basic framework was shown in Figure 2. In the figure, the degree of internal and external coordination is the external area of human resources development and management system coordination reflected. 


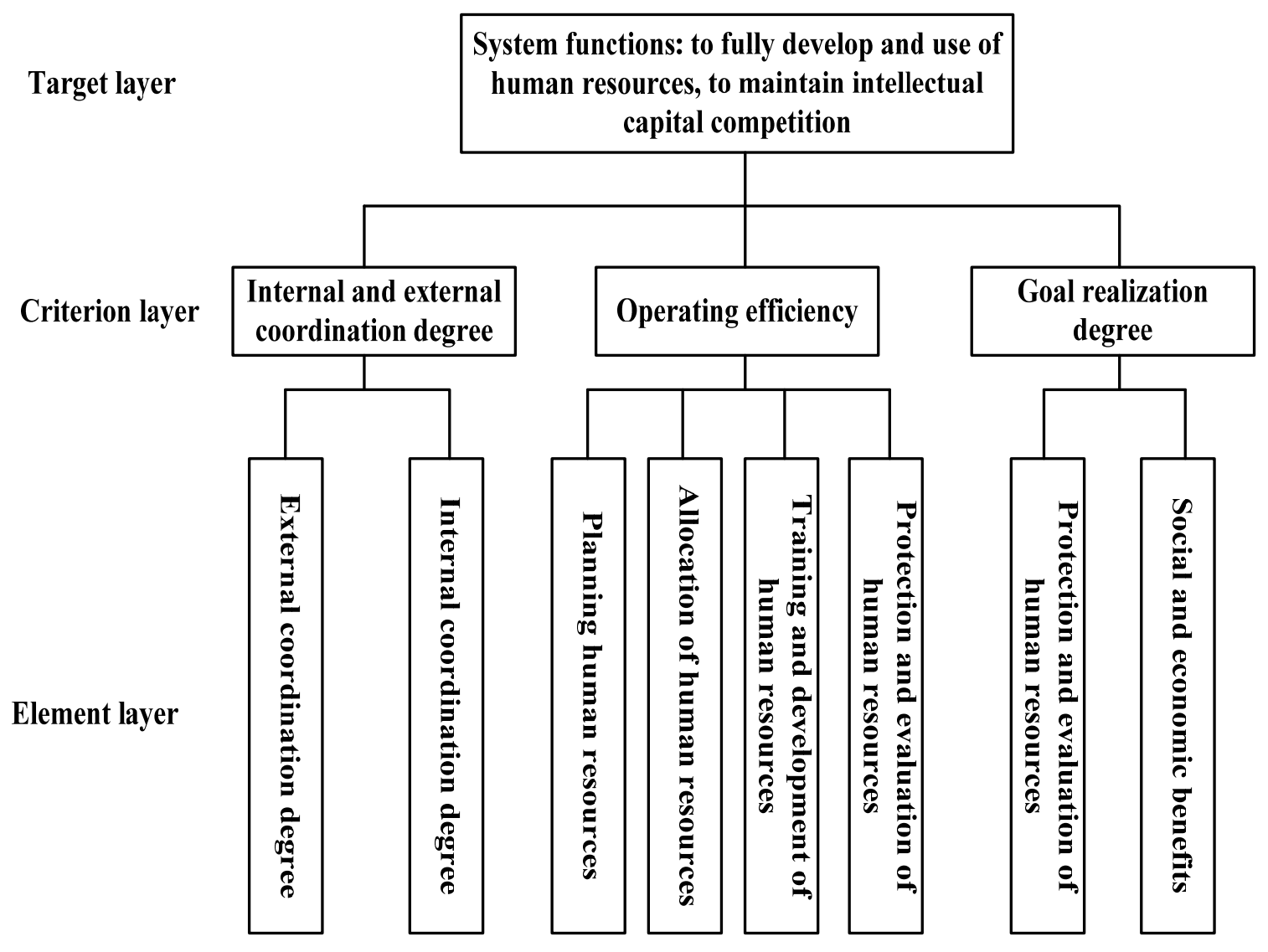

Figure 2. Regional development and human resource management evaluation index system basic framework

In the figure, the degree of internal and external coordination is the external area of human resources development and management system coordination reflected. According to the system theory, regional human resource development and management systems at the same time by other subsystems of economic system, social system, affecting areas like the labor market, it should take full account of coordination between the various systems, this external coordination; the same time, the regional human resource development and management system is the regional components of large-scale systems, constrained by the regional development objectives of the regional interplay of human resources development and management between the various elements within the system, mutual cooperation decided by the human resource development and management system function, this is the internal coordination.

\section{Evaluation Index System}

According to the basic framework of regional human resources development and management evaluation system, combined with previous research, this paper constructs evaluation of regional human resource development and management performance indicators, as shown in Table 1.

With the deepening of reform of the personnel system, Regional Human Resource Development and Management also assumes an international, integrated, multi-level trend. These make the index system of regional human resources development and management system evaluations to the multi-level systematic, multi-dimensional direction. Which makes the area of human resources development and management more complex, involving more objects, broader, subjective and 
objective factors make many constraints and evaluation of the regional human resources development and management is very complicated. Operability, practicality, and the establishment of evaluation model index system problems in the future remains to be more in-depth discussion from theory and practice.

Table 1.Evaluation index system of regional human resource development and management

\begin{tabular}{|c|c|c|c|}
\hline $\begin{array}{l}\text { Target } \\
\text { layer }\end{array}$ & $\begin{array}{c}\text { Criterion } \\
\text { layer }\end{array}$ & $\begin{array}{c}\text { Element } \\
\text { layer }\end{array}$ & Index layer \\
\hline $\begin{array}{c}\text { A } \\
\text { Huma } \\
n \\
\text { resour } \\
\text { ce } \\
\text { devel } \\
\text { opme } \\
\text { nt and } \\
\text { mana } \\
\text { geme } \\
\text { nt } \\
\text { perfor } \\
\text { manc } \\
\text { e }\end{array}$ & $\begin{array}{c}\text { B1 } \\
\text { Coordination } \\
\text { degree }\end{array}$ & $\begin{array}{c}\text { C2 Internal } \\
\text { coordination } \\
\text { degree }\end{array}$ & $\begin{array}{l}\text { D1Adaptability of labor market } \\
\text { D2 Compliance } \\
\text { D3 Employee collaboration degree } \\
\text { D4 Information feedback speed } \\
\text { D5 Growth rate of human resources } \\
\text { D6 Proportion of professional and technical } \\
\text { personnel } \\
\text { D7 Average number of years of Education } \\
\text { D8 Job search rate } \\
\text { D9 Human resource draw } \\
\text { D10 Reaction time } \\
\text { D11 Manning number } \\
\text { D12 Post structure of staff and workers } \\
\text { D13 Cultural structure of staff and workers } \\
\text { D14 Travel allowance } \\
\text { D15 Position management gradient }\end{array}$ \\
\hline
\end{tabular}

\section{Summary}

According to the new theory of economic growth and human capital theory (Schultz), human resources as an intangible asset, it is compared with the other factors of production of natural resources, technology, capital, etc., when it is deeply penetrated into society when the system is running, created by the competitive advantage increasingly difficult to imitate, and persistent. Human resources as a subsystem of the social system, development and management of human resources and give full play to their potential to enhance the competitiveness of the region continued to have a very important position, and therefore the area of human resources development and management performance measure were found regional human resource development and management in the problems of human resource development and management for the region and contribute to regional strategic objectives provide important basis for decision making.

\section{References}

[1] Ali B A A, Sapuan S M, Zainudin E S, et al. Implementation of the expert decision system for environmental assessment in composite materials selection for automotive components[J]. Journal of Cleaner Production, 2015.

[2] Babuska R,Verbruggon H B,Bancan H J L.Fuzzy modeling of enzymatic penicillin-G Anversion. Engineering Application of Artificial Intelligence,1999,12(1): 79-72.

[3] Xiao W,Weidemann B.Fuzzy modeling and its application to magnetic bearing systems.Fuzzy Sets and Systems,1995,73(20): 20-217.

[4] Lee Chang Jun, Prasad Binay, Lee Jong Min. Stochastic nonlinear optimization for robust design 
of catalysts. Industrial and Engineering Chemistry Research,2011,50(7): 3938-394.

[5] Y. Zhao, W. Wei, X.J. Tang, M.L. Zhao, Choice of Optimized Scheme Parameters of Neural Networks Based on Error Handling, AISS. 17(2012)76-82.

[6] Ho H P. The Influence of Braking System Component Design Parameters on Pedal Force and Displacement Characteristics. Simulation of a passenger car brake system, focusing on the prediction of brake pedal force and displacement based on the system components and their design characteristics[D]. University of Bradford, 2015.

[7] Diakaki C, Papageorgiou M, Papamichail I, et al. Overview and analysis of Vehicle Automation and Communication Systems from a motorway traffic management perspective[J]. Transportation Research Part A: Policy and Practice, 2015, 75: 147-165.

[8] Wang B, Huang X, Wang J, et al. A robust wheel slip ratio control design combining hydraulic and regenerative braking systems for in-wheel-motors-driven electric Vehicles[J]. Journal of the Franklin Institute, 2015, 352(2): 577-602.

[9] Reaidy P J, Gunasekaran A, Spalanzani A. Bottom-up approach based on internet of things for order fulfillment in a collaborative warehousing environment[J]. International Journal of Production Economics, 2015, 159: 29-40.

[10]Gonzalez E D R S, Sarkis J, Huisingh D, et al. Making real progress toward more sustainable societies using decision support models and tools: Introduction to the special volume[J]. Journal of Cleaner Production, 2015. 